\title{
MECHANISM OF PUBLIC MANAGEMENT OF THE SYSTEM OF DEVELOPMENT OF INTELLECTUAL RESOURCES OF THE ECONOMY OF UKRAINE
}

\begin{abstract}
Nikolay Shopsha ${ }^{1}$, Tykhon Yarovoi ${ }^{2}$
${ }^{1}$ Senior Lecturer, Department of Psychology, PJSC "Interregional Academy of Personnel Management", Kyiv, Ukraine, e-mail: tikhon_9563963@ukr.net, ORCID: https://orcid.org/0000-0002-4361-039X

${ }^{2}$ Candidate of Sciences (Public Administration), Associate Professor, Associate Professor Interregional Academy of Personnel Management (Kyiv), Department of Public Administration, Kyiv, Ukraine, e-mail: tikhon_9563963@ukr.net,ORCID: https://orcid.org/0000-0002-7266-3829
\end{abstract}

\begin{abstract}
The article presents the structure of the mechanism of public management of the system of intellectual resources development, which will contribute to the development of intellectual resources and increase the efficiency of their use and is able to function offline, taking into account the peculiarities of socio-economic development and ensures the expansion of the range of means and methods of management. The application of the mechanism of public management of the intellectual resources development system and the model of formation, use and development of intellectual resources in practice will contribute to the improvement of regulatory and legal support for the management of intellectual resources, the introduction of new spatial forms of innovation and attraction of investments in the development of intellectual resourceswill significantly increase the intellectual development of our country, and innovative development will contribute to the growth of a new intellectual resource. The combined methods of intellectual resource management in four groups: organizational: definition of structure, tasks, functions of intellectual resources; approval of norms and standards in the field of intellectual resources management; approval of methods and recommendations; financial and economic: investing in the formation and use of intellectual resources; pricing for intelligent resources; socio-psychological: creation of creative atmosphere in the workplace; formation of principles and norms of behavior in order to increase creative activity; $P R$ events (public relations - "public relations"); legal: application of laws and other regulations on copyright protection, as well as protection against unfair competition and intellectual piracy; administrative: these are methods of influence of public administration on society where intellectual resources are formed and characterized by relations "power-society".
\end{abstract}

Keywords: intellectual resources, public administration, development, education, mechanism.

JEL Classification: H10, H75, J01

Formulas: 0; fig.: 1; tabl.: 0; bibl.: 7

Introduction. In the current conditions of economic development of Ukraine, the theoretical foundations of effective management of the formation and use of intellectual resources require careful study, after all, information, scientific knowledge, professional, scientific and cultural potential of society determines the structure of the national economy, the quality of manufactured products, the provision of services.

Literature Review. The search for directions and measures to improve the management of intellectual resources is presented in the scientific works of such domestic Nukovs as: O. Amosov, V. Bzalyevich, I. Bilous, N. Gavkalova, V. Geyts, B. Dergalyuk, Y. Zaitseva, S. Kis, N. Kravchuk, L. Kurylo, L. Lazebnik, G. Lyashenko, E. Libanova, V. Mandybury, R. Marutyan, Y. Pashomov, O. Popelo, V. Savchuk, L. Fedulova, A. Chukno, V. Yakubenko and others.

At the same time, many issues in the Ukrainian and foreign scientific literature 
are related to the study of the peculiarities of managing the development of intellectual resources in the economy of Ukraine requires careful research.

Aims. The purpose of the article is to substantiate the scientific and applied principles of formation and implementation of the mechanism of public management of the system of development of intellectual resources of the economy of Ukraine.

Methods. The author used the methods of static and logical comparison, systematization and generalization, which made it possible to achieve the goal of the study.

Results. In a broad sense, the "management mechanism" is the process of the agreed influence of the management entity on the phenomena of social reality surrounding it.

Summarizing the above interpretations of the term "management mechanism" can be defined as a set of means, functions, methods, legal, organizational, administrative, motivational measures aimed at ensuring the dynamic development of society [2] and the country as a whole, the components of which are specific management mechanisms (economic, motivational, political, legal, etc.), which together are able to ensure the balanced and effective functioning of a single mechanism.

In our opinion, the mechanism of public management of the development of intellectual resources is a system of elements: forms, methods, functions, principles and tools by which the state influences society in order to manage the formation and use of intellectual resources aimed at the implementation of goals.

Theechanism of management of the system of formation and use of intellectual resources of Ukraine is a cycle structure in the form of a continuous and rather dynamic process.

The State is the main regulator of the formation and use of intellectual resources in the country's economy with the help of regulatory, administrative, financial, economic, information and organizational levers in order to target the Ministry of Education and Science to achieve the goals and priorities of the state scientific and educational policy.

The state can perform its functions of influencing the economy directly through financing the development of the public sector, science, culture, education, social protection of the population or indirectly - through a system of legal and economic regulators. .

The main branch of the state that influences the formation, development and use of intellectual resources is scientific and educational - the central body of which is the Ministry of Education and Science of Ukraine, which ensures the formation and implementation of state policy in the fields of education and science, intellectual property, scientific, scientific, technical and innovative activities, informatization, development of national electronic information resources, creates conditions for the development of the information society, and also carries out where rusty supervision over the activities of educational institutions, regardless of their subordination and form of ownership. 


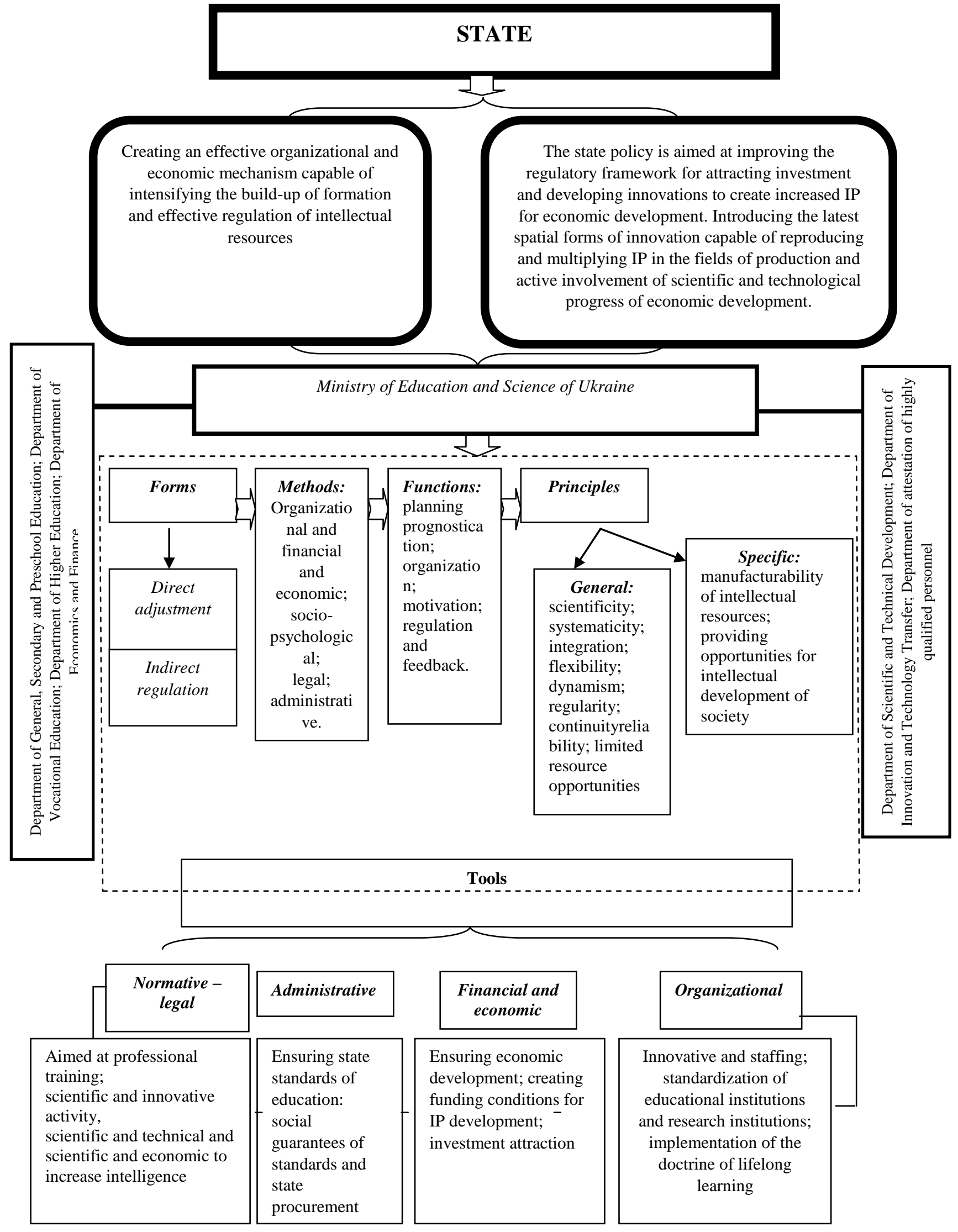

\section{Figure 1. Mechanism of public management of the system of formation and use of intellectual resources}

Source: developed by author 
The Ministry of Education and Science through the Department of General, Secondary and Preschool Education: in the formation and implementation of the state policy on the development of general secondary and preschool education; formation of a regulatory framework and conditions for obtaining preschool and complete general secondary education for children; - ensures the right to education for children in need of state assistance and support: orphans and children deprived of parental care, children with special educational needs, including children with disabilities, through the introduction of inclusive learning; who are in conflict with the law; development of priority areas of general secondary, special and preschool education; development of state requirements for determining the procedure for state control over the activities of preschool and comprehensive educational institutions, selection of managerial personnel and management activities in preschool and general secondary education; promotes the integration of the national education system into the European and world educational space; coordination of activities of institutes of postgraduate pedagogical education on general secondary and preschool education; introduction of innovative educational technologies, which are based on the principles of taking into account the interests of a child with special needs;

The Department of Vocational Education determines the prospects and directions of development of vocational education; provides interaction with other fields of education; carries out normative and methodological support for the functioning of vocational schools; monitors the implementation of state policy; determines on the basis of state order and labor market needs the volumes of training, retraining and advanced training in vocational schools; determines the strategy for monitoring the quality of education and ensures its implementation; provides, together with local education management, optimization of the network of educational institutions of vocational education;

The main tasks of the Department of Higher Education are: conducting analytical and prognostic activities in the field of higher education, identifying trends in its development, the influence of the demographic, ethnic, socio-economic situation, the infrastructure of the production and non-production sphere; formation of strategic directions of higher education development, development of organizational and legal mechanism of its functioning taking into account scientific and technological progress and other factors; development of draft legislative acts and normative documents on higher education; participation in the formation and implementation of state policy in the field of higher education, coordination of work on higher education of central executive bodies, which include higher education institutions; formation of proposals and placement of a state order for the training of specialists with higher education; development of admission system to higher educational institutions; development and implementation of a career guidance system for young people for higher education and the creation and practical implementation of programs for identifying and educational growth of talented youth; formation of a list of fields of knowledge and a list of specialties on which higher education applicants are trained; organization of development of standards of educational activity and standards of higher education; organization of training in the 
level system of higher education, integration of educational institutions of various types into educational, educational, research and production complexes; organization of the system of pre-university education; participation in the organization of the educational process and state certification during the training, retraining and advanced training of personnel in higher educational institutions and postgraduate education institutions; participation in the organization of professional and practical training of personnel, assistance to higher educational institutions in the selection of places of industrial practice and employment of graduates; formation of tasks for conducting scientific research on the problems of higher education; generalization of world and domestic experience in the development of higher education; organizational work on the integration of Higher Education of Ukraine into the European Higher Education Area [4].

The Department of Scientific and Technical Development is responsible for organizing and ensuring the implementation of the functions of the Ministry on the formation and implementation of state policy in the field of science, scientific and scientific and technical activities.

In particular, it concerns the issues of state certification of scientific institutions, the system of scientific and scientific and technical expertise, support for the development of scientific and technical infrastructure, social protection of scientific workers, coordination of the development of projects of state target scientific and scientific and technical programs, the formation and implementation of state procurement for scientific and technical products, etc. Having a powerful system of higher educational institutions and scientific institutions in the field of their management, the Ministry provides financial support and promotes their research and development, stimulates the involvement of young people in scientific activities [5].

The Department of Innovation and Technology Transfer improves the legal conditions for innovation and technology transfer; ensures the development of innovative infrastructure in order to assist scientists, inventors and enterprises throughout the innovation chain: scientific and technical development - innovation production; promoting the commercialization of intellectual property rights and transferring technologies to enterprises to create the production of competitive products; developing and introducing effective mechanisms of state support and attracting financial resources for the implementation of innovative projects.

Department of attestation of personnel of higher qualification ensures the formation of a network of specialized academic councils, postgraduate, adjunct and doctoral studies, providing and analyzing their activities;

The main tasks of the Department of Economics and Finance are:participation in the formation, preparation and definition of indicators of the draft law on the State Budget of Ukraine for the corresponding year in the sections "Education" and "Science"; development and bringing to the departmental institutions and institutions the amount of expenditures of budget funds for the relevant year; ensuring timely and full financing of expenditures under the sections "Education" and "Science" within the budgetary appointments provided for by the Law of Ukraine on the State Budget for the relevant year; analyzes the use of budget funds in the context of budget 
programs; participates in the development and improvement of conditions and remuneration of employees of budgetary institutions and organizations of the educational sector; develops annual and long-term state programs of economic and social development of educational institutions and institutions on issues within the competence of the department.

The mechanism of management of the formation and use of intellectual resources reacts to the environmental impact and the less oscillations in it, the more stable the system that adapts and develops. To increase intellectual resources and increase the efficiency of their use, a comprehensively thought-out and effective national intellectual system with regional subsystems capable of functioning offline, taking into account the peculiarities of regional socio-economic development, is necessary.

Forms of public administration are divided into direct management, which include: determining state priorities for the development of education, science and technology; state educational, scientific and technical programs; state order in the educational and scientific and technical sphere; budget financing of education, research and works carried out within the framework of priority directions of education, science and technology development; training of scientific and technical personnel; and indirect management:instruments of financial and budgetary, tax policy; legal protection of intellectual property; state policy in the field of international scientific and technical cooperation.

Methods of intellectual resources management are a purposeful procedure for the management subsystem and the use of management techniques for intellectual resources in compliance with the relevant conditions and restrictions. We combine intelligent resource management methods into four groups:

1. Organizational: definition of structure, tasks, functions of intellectual resources; approval of norms and standards in the field of intellectual resources management; approval of methods and recommendations.

2. Financial and economic: investing in the formation and use of intellectual resources; pricing for intellectual resources.

3. Socio-psychological: creating a creative atmosphere in the workplace; forming principles and norms of behavior in order to increase creative activity; PR ( relations - "public relations").

4. Legal: application of laws and other regulations on copyright protection, as well as protection against unfair competition and intellectual piracy..

Administrative: these are methods of influence of public administration on society where intellectual resources are formed and characterized by relations "power - society", improvement of the system of public administration. Such a methodological approach of the main regulator in the person of the state is necessary to coordinate efforts to form effective mechanisms in the public administration system.

Six functions of ensuring the development of intellectual resources are highlighted in the work:

1) planning are actions and solutions aimed at developing specific strategies 
designed to help the state achieve its goals. Expenditures from the state budget for education in 2015 decreased by $16.3 \%$ compared to the previous year and amounted to UAH 1.6 billion, therefore, accordingly,the volume of state procurement for the training of specialists with higher education, the future may hinder the development of intellectual resources;

2) forecasting - the application of the acquired experience, skills and current assumptions in order to determine the future development of intellectual resources;

3) organization - the process of creating and establishing work, which enables people to work effectively to achieve a common goal using their knowledge;

4) motivation consists in providing conditions for the formation of intellectual resources - creating favorable working conditions, updating technological support and providing premises for practical research, which together will contribute to the increase of intelligence;

5) management is a management process that is carried out using methods of formal influence and strengthened (power and leadership) in order to preserve the stability of the state by maintaining the necessary ratio between their different elements, timely elimination of possible deviations from the established norms in the functioning of management objects [6].

The formation of a mechanism for managing the formation and use of intellectual resources as a system is based on scientific principles:

- the principle of scientificity - methods, means of management of the formation and use of intellectual resources should be scientifically justified and proven by practice;

- the principle of systemicity consists in establishing between the structural elements of the information system of communications that ensure the integrity of the functioning of the management mechanism of the system of development of intellectual resources;

- the principle of integration - the interaction of all forms, elements and methods of formation and use of intellectual resources and their organization into a single system at all levels of development;

- the principle of flexibility, which means the ability of the mechanism plan to change its direction when changing the conditions of activity and have certain reserves.

- the principle of dynamism assumes that the IP control mechanism must be adapted to the requirements of the external and internal environment;

- the principle of systematism means that the management system should be aimed at solving not only current but also long-term problems of intellectual capital development [5-6];

- the principle of continuity and reliability is manifested in the creation of organizational and economic conditions that will contribute to the stability and continuity of the effective functioning of intellectual resources;

- the principle of limited resource capabilities provides for the effective use of all types of resources.

Specific principles of the mechanism model include: 
- ensuring the manufacturability of intellectual resources development;

- providing opportunities for intellectual development of society.

Taking into account the specifics of intellectual resources, it is advisable to use combined techniques that involve several management methods at the same time. With the complex action of levers, the impact on the process of intellectual resource management can be strengthened, weakened or completely neutralized depending on how rationally their regulatory values are established.

The tools of the mechanism are the main means of applying the mechanism of public management of the formation and use of intellectual resources in the economy of Ukraine, among them normative legal - laws of Ukraine, resolutions of the Cabinet of Ministers, orders and instructions of central executive bodies aimed at professional training, scientific-innovative, technical, economic activities to increase intelligence; administrative - development and approval of standards of education, social guarantees and state order for training; financial-economic - income of employees of the scientific and educational sector, state spending on research work, financing of education.

The organizational tools of the intellectual resources management mechanism include:

- innovative support - technological and technical renewal of basic sectors of the economy; implementation of highly profitable innovation and investment projects;

- personnel support is personnel planning.

- ensuring control contributes to the achievement of the main cost goal of institutions, optimization of financial results, through maximization of profit and capital value with guaranteed liquidity.

Discussion. For the effective action of the mechanism it is necessary:

- tocreatelegal and prerequisites forthe exit of education from a crisis state, the transformation of the educational regulatory framework into an effective tool for quality management and improving the effectiveness of education;

- to create favorable conditions for the development of higher education, the development of the best national educational and cultural traditions, which will contribute to the comprehensive development and education of Ukrainian citizens;

- to increase the prestige of science and scientific activity, the development of innovation activities, the formation of the information society and the economics of knowledge;

- to ensure harmonious interaction of national systems of education, science, economics and modernization of the system of training specialists with higher education, taking into account the needs of the person, interests of the state, territorial communities and employers;

- to create conditions for stimulating business entities to introduce innovations;

- to concentrate state financial resources on breakthrough directions of scientific and technical development by changing the system of formation and implementation of priority directions of innovation activity;

- to ensure the protection of intellectual property as a prerequisite for the successful commercialization of scientific developments; 
- to stimulate the scientific and technical potential of Ukraine to introduce the latest technologies and developments, as well as to establish effective interaction between business entities and state authorities in the field of technology transfer;

- to create favorable conditions for the development and use of scientific and technical potential of Ukraine.

Conclusions. A mechanism for public management of the intellectual resource development systemhas been developed, the application of which will improve the regulatory and legal support of intellectual resourcesmanagement, the introduction of new spatial forms of innovation and attraction of investments in the development of suchresources will be implemented, which will significantly increase theintellectual development of Ukraine. The model of formation, use and development of intellectual resources in the economy of Ukraine was built, which will ensure effective management of intellectual resources of the national economy and their innovative development through scientific and technological progress, IT technology and the formation of a virtual economy, high standards of ensuring protection, cultural and educational level of society, health, which significantly affect the development of intellectual resources; staffing potential, scientific potential, innovation potential, productivity, migration of scientific personnel are factors that affect the use of intellectual resources; conditions for the growth of intellectual resources and dynamic development, social guarantees, patriotism of the population, social standards, responsibility to society, balance of the labor market are factors thataffect the development of intellectual resources.

Author contributions. The authors contributed equally.

Disclosure statement. The authors do not have any conflict of interest.

\section{References:}

1. Marutian, R. (2012), "Intellectual resources of public administration in the system of state power", Zbirnyk naukovykh prats' Natsional'noi akademii derzhavnoho upravlinnia pry Prezydentovi Ukrainy, vol. 1, pp. 277-286, available at: http://nbuv.gov.ua/UJRN/znpnadu_2012_1_30 (Accessed 03.09.2020).

2. Bilous, I.M. (2016), "Protection of intellectual property rights: Ukrainian and foreign experience", Visnyk Mariupol's'koho derzhavnoho universytetu. Seriia: Pravo, vol. 11, pp. 20-27, available at: http://nbuv.gov.ua/ UJRN/Vmdu_pr_2016_11_4 (Accessed 03.09.2020).

3. Popelo, O.V. (2015), "Intellectual capital: theoretical aspect and current trends in Ukraine", Ekonomika i rehion, vol.

2, pp. 66-78, available at: http://nbuv.gov.ua/ UJRN/econrig_2015_2_14 (Accessed 03.09.2020).

4. Kurylo L.I. (2006), "Intellectual capital: theoretical aspect", Akademiia munitsypal'noho upravlinnia, [Online], vol.

9, available at: http://www.rusnauka.com/NIEK_2006/Economics/9_17570.doc.htm (Accessed 03.09.2020).

5. Kis' S.Ya. (2016), "Scientific bases of intellectualization of activity of the enterprises", Abstract of Dr. ek. Science dissertation, economics and business management (by type of economic activity), Ivano-Frankivsk National Technical University of Oil and Gas, Ivano-Frankivsk, Ukraine.

6. Kravchuk N. O. (2013), "Consumer capital as an element of intellectual capital: essence and structure", Efektyvna ekonomika, vol. 7, available at: http://www.economy.nayka.com.ua/?op=1\&z=2199 (Accessed 03.09.2020).

7. Shemayeva, L., Mihus, I., Shemayev, V., Shemayev, V., \& Melnyk, L. (2020). APPLICATION OF THE MODEL OF CROSS-OPTIMIZATION OF FINANCIAL AND MATERIAL FLOWS IN THE MECHANISM OF PROVISION OF FINANCIAL SECURITY. Financial And Credit Activity: Problems Of Theory And Practice, 2(33), 400-410. doi:http://dx.doi.org/10.18371/fcaptp.v2i33.207078 